\title{
Implementasi Metode Runge-Kutta-Gill pada Anaerobic Digestion Model No. 1 untuk Memodelkan Produksi Biogas
}

\author{
Ardhyka Dewantara ${ }^{1}$, Rian Febrian Umbara ${ }^{2}$, Isman Kurniawan ${ }^{3}$ \\ Jurusan Ilmu Komputasi, Fakultas Informatika, Telkom University \\ Jl. Telekomunikasi No. 1 Terusan Buah Batu, Bandung, Indonesia \\ ${ }^{1}$ ardhyka@bclaboratory.com \\ 2 rianum123@gmail.com \\ 3 isman.krn@gmail.com
}

\begin{abstract}
Abstrack
This research aimed to investigate the reliability of Runge-Kutta-Gill method to solve Anaerobic Digestion Model No. 1 that used to produce biogas. This model is a suitable model for anaerobic process. The condition of simulation was adjusted to experimental condition, while the standard parameters was used in the calculation. The results indicate the significant increasing of glucose along with the increasing of methane. Besides, correlation investigation between initial concentration of glucose and produced methane gives a strong correlation between them. However, the accuracy of the calculation should be improved by optimizing the parameters using such optimization method.
\end{abstract}

Keywords: Biogas, Anaerobic Digestion Model No. 1, Runge-Kutta-Gill method

\begin{abstract}
Abstrak
Penelitian ini dilakukan untuk mengetahui kehandalan metode Runge-Kutta-Gill dalam menyelesaikan model ADM1 pada produksi biogas. Model ini merupakan model yang cocok untuk diterapkan pada proses anaerobik. Kondisi simulasi disesuaikan dengan kondisi eksperimen acuan dan parameter yang digunakan merupakan parameter standar ADM1. Hasil simulasi menunjukkan terjadinya penurunan konsentrasi glukosa yang signifikan bersamaan dengan peningkatan konsetrasi metana. Selain itu, uji korelasi antara konsentrasi awal glukosa dan konsentrasi metana menunjukkan korelasi berbanding lurus antara kedua variabel tersebut. Akan tetapi, akurasi perhitungan masih perlu ditingkatkan dengan mengoptimasi parameter ADM1 dengan suatu metode optimasi.
\end{abstract}

Kata Kunci: Biogas, Anaerobic Digestion Model No. 1, Metode Runge-Kutta-Gill

\section{PENDAhUluan}

$\mathbf{K}$ RISIS energi merupakan permasalahan yang sedang dihadapi oleh berbagai negara di dunia, termasuk Indonesia. Untuk mengatasi permasalahan tersebut, diperlukan sumber daya energi alternatif yang dapat diperbaharui. Salah satu alternatif energi alternatif yang cukup menjanjikan adalah biogas [1]. Penggunaan biogas dapat menekan emisi gas rumah kaca yang dapat menyebabkan perubahan iklim [2]. Selain itu, biogas dapat diproduksi dengan memanfaatkan limbah organik sehingga dapat menjadi solusi untuk masalah pengolahan sampah, terutama di daerah perkotaan [3].

Terkait dengan produksi biogas, studi secara komprehensif perlu dilakukan untuk meningkatkan efisiensi produksinya. Kompleksitas proses yang terjadi pada produksi biogas menuntut penggunaan suatu model matematika untuk dapat mempelajari proses produksi dengan akurat. Pada tahun 2012, International Water 
ARDhYKA DEWANTARA ET.AL.

Implementasi Metode Runge-Kutta-Gill...

Association (IWA) telah mengajukan suatu model yang cocok untuk digunakan pada proses anaerobik, seperti produksi biogas, yang dinamakan Anaerobic Digestion Model No. 1 (ADM1) [4]. Model ini sangat populer dimana lebih dari 750 publikasi yang dihasilkan terkait dengan studi proses anaerobik dengan ADM1 pada 30 tahun terakhir [5].

Derbal dkk. menggunakan ADM1 untuk mensimulasikan pengolahan anaerobik dari sampah organik dengan limbah lumpur aktif pada kondisi mesofilik [6]. Lalu Soda dkk. memodifikasi ADM1 untuk diterapkan pada eksperimen jangka panjang yang menghasilkan kombinasi gas metana dan hidrogen dari suatu model sampah organik [7]. Selanjutnya, Satpathy, dkk. menggunakan model ADM1 untuk memprediksi produksi biogas serta mengetahui dinamika proses yang terlibat [8]. Validasi terhadap model matematika ADM1 dilakukan oleh Yu, dkk untuk mempelajari secara mendalam terhadap proses kompleks yang terjadi, seperti transport phenomena, kinetika biokima dan hubungan stoikiometri pada ADM1 [9].

Berdasarkan studi-studi tersebut, model ADM1 digunakan pada penelitian ini karena merupakan model yang paling cocok untuk digunakan pada proses anaerobik. Penyelesaian model ADM1 dilakukan dengan menyelesaikan sistem persamaan diferensial dengan suatu metode numerik. Pada penelitian ini, metode Runge-Kutta-Gill digunakan untuk menyelesaikan model ADM1. Model ini merupakan modifikasi dari Runge Kutta yang diajukan oleh Gill [10] dan biasa digunakan untuk menyelesaikan model kinetika biomolekul [11]. Tujuan utama penelitian ini adalah mengetahui kehandalan metode Runge-Kutta-Gill dalam menyelesaikan persamaan model ADM1. Selain itu, korelasi beberapa variabel yang terlibat dalam proses biokimia juga diinvestigasi dan dapat diterapkan untuk memprediksi konsentrasi metana yang dihasilkan.

\section{Metode Penelitian}

Kinetika reaksi untuk masing-masing spesi yang terlibat dimodelkan dengan menggunakan Anaerobic Digestion Model No. 1 (ADM1). Pada model ini, parameter yang digunakan pada pemodelan dan simulasi dilakukan dengan mengacu pada kondisi eksperimen [12], dimana glukosa digunakan sebagai substrat awal dengan konsentrasi awal $500 \mathrm{mgCOD} / \mathrm{L}$. Selain itu, penyusunan model kinetika reaksi disesuaikan dengan produksi biogas pada reaktor tipe batch. Meskipun biogas tersusun dari tiga komponen gas, tapi pada penelitian ini hanya gas metana yang dilibatkan dalam model kinetika. Pembentukan gas metana diasumsikan terjadi secara spontan sehingga proses transfer gas dapat diabaikan. Selain itu, konsentrasi karbondioksida tidak dipertimbangkan karena konsentrasinya lebih kecil secara signifikan dibandingkan konsentrasi spesi yang lain.

Kinetika reaksi yang dipertimbangkan dalam penelitian ini hanya melibatkan poses biokimia (Gambar 1) dan mengabaikan proses fisiko-kimia. Hal ini dikarenakan proses biokimia merupakan proses yang paling dominan pada model ini. Berdasarkan proses biokimia tersebut, korelasi antara spesi dan laju reaksi ditunjukkan secara sederhana menggunakan matriks pada Tabel I, dimana nomor komponen dan proses merujuk pada ADM1 [4]. Persamaan laju yang terdapat pada matriks tersebut ditunjukkan oleh Persamaan 1 - 10, dimana nilai parameter yang digunakan mengacu pada nilai standar ADM1 (Tabel II). Selanjutnya, model matematika dibangun berdasarkan sistem persamaan diferensial dengan mengimplementasikan persamaan 11 terhadap matriks proses biokimia. Deskripsi spesifik dari parameter-parameter serta satuannya dijelaskan pada tabel daftar notasi.

Dengan menggunakan model matematika yang telah disusun, simulasi produksi biogas dilakukan untuk mengetahui profil perubahan konsentrasi tiap spesi terhadap fungsi waktu. Analisis akurasi perhitungan dilakukan dengan membandingkan konsentrasi metana hasil perhitungan dengan data eksperimen [12]. Uji T dan Mean Absolute Percentage Error (MAPE) dilakukan untuk menentukan tingkat akurasi nilai tiap titik dan rata-rata. Beberapa analisis korelasi juga dilakukan untuk mengetahui hubungan variabel yang terlibat dalam simulasi. Analsis tersebut adalah korelasi langkah simulasi dan total waktu simulasi serta korelasi konsentrasi awal glukosa dan mikroba terhadap konsentrasi metana yang dihasilkan. 


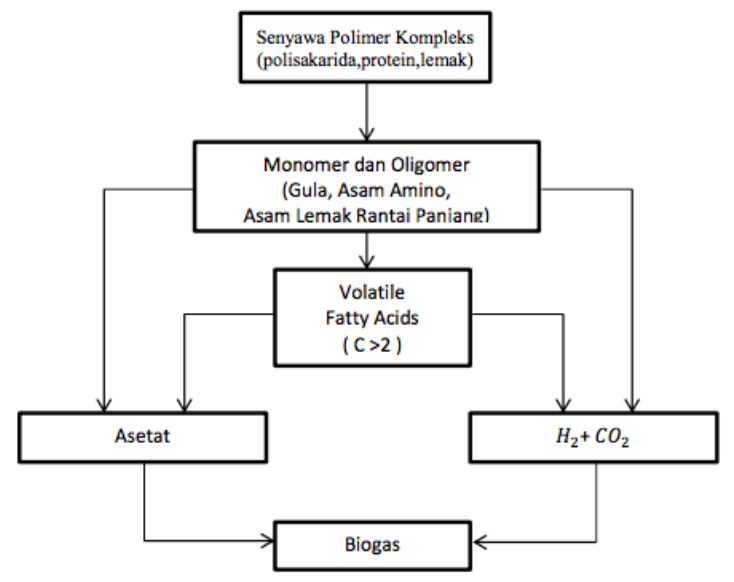

Gambar 1: Proses biokimia pada ADM1

Tabel I: Matriks proses biokimia

\begin{tabular}{|c|c|c|c|c|c|c|c|c|c|c|c|c|c|}
\hline \multicolumn{2}{|c|}{ Komponen } & 1 & 2 & 3 & 4 & 5 & 6 & 8 & 9 & 10 & 11 & 12 & \multirow{2}{*}{ Laju } \\
\hline (j) & Proses & $\mathbf{S}_{\mathrm{su}}$ & $\mathbf{S}_{\mathrm{bu}}$ & $\mathbf{S}_{\text {pro }}$ & $\mathbf{S}_{\mathrm{ac}}$ & $\mathbf{S}_{\mathrm{h} 2}$ & $\mathbf{S}_{\mathrm{ch} 4}$ & $\mathbf{X}_{\mathrm{su}}$ & $\mathbf{X}_{\mathrm{c} 4}$ & $\mathbf{X}_{\text {pro }}$ & $\mathbf{X}_{\mathrm{ac}}$ & $\mathbf{X}_{\mathrm{h} 2}$ & \\
\hline 5 & Penguraian glukosa & -1 & $\left(1-Y_{\mathrm{su}}\right) f_{\mathrm{bu}, \mathrm{su}}$ & $\left(1-Y_{\mathrm{su}}\right) f_{\mathrm{pro}, \mathrm{su}}$ & $\left(1-Y_{\mathrm{su}}\right) f_{\mathrm{ac}, \mathrm{su}}$ & $\left(1-Y_{\mathrm{su}}\right) f_{\mathrm{h} 2, \mathrm{su}}$ & & $Y_{\mathrm{su}}$ & & & & & $\rho_{5}$ \\
\hline 9 & Penguraian butirat & & -1 & & $\left(1-Y_{\mathrm{c} 4}\right) 0.8$ & $\left(1-Y_{\mathrm{c} 4}\right) 0.2$ & & & $Y_{\mathrm{c} 4}$ & & & & $\rho_{9}$ \\
\hline 10 & Penguraian propionat & & & -1 & $\left(1-Y_{\text {pro }}\right) 0.57$ & $\left(1-Y_{\text {pro }}\right) 0.43$ & & & & $Y_{\text {pro }}$ & & & $\rho_{10}$ \\
\hline 11 & Penguraian asetat & & & & -1 & & $\left(1-Y_{\mathrm{ac}}\right)$ & & & & $Y_{\mathrm{ac}}$ & & $\rho_{11}$ \\
\hline 12 & Penguraian hidrogen & & & & & -1 & $\left(1-Y_{\mathrm{h} 2}\right)$ & & & & & $Y_{\mathrm{h} 2}$ & $\rho_{12}$ \\
\hline 13 & Pembusukan mikroba $X_{\text {su }}$ & & & & & & & -1 & & & & & $\rho_{13}$ \\
\hline 16 & Pembusukan mikroba $X_{\mathrm{c} 4}$ & & & & & & & & -1 & & & & $\rho_{16}$ \\
\hline 17 & Pembusukan mikroba $X_{\text {pro }}$ & & & & & & & & & -1 & & & $\rho_{17}$ \\
\hline 18 & Pembusukan mikroba $X_{\mathrm{ac}}$ & & & & & & & & & & -1 & & $\rho_{18}$ \\
\hline 19 & Pembusukan mikroba $X_{\mathrm{h} 2}$ & & & & & & & & & & & -1 & $\rho_{19}$ \\
\hline
\end{tabular}

$$
\begin{aligned}
\rho_{5} & =k_{\mathrm{m}, \mathrm{su}} \frac{S_{\mathrm{su}}}{K_{\mathrm{S}, \mathrm{su}}+S_{\mathrm{su}}} X_{\mathrm{su}} \\
\rho_{9} & =k_{\mathrm{m}, \mathrm{c} 4} \frac{S_{\mathrm{bu}}}{K_{\mathrm{S}, \mathrm{bu}}+S_{\mathrm{bu}}} X_{\mathrm{c} 4} \\
\rho_{10} & =k_{\mathrm{m}, \mathrm{pro}} \frac{S_{\mathrm{pro}}}{K_{\mathrm{S}, \mathrm{pro}}+S_{\mathrm{pro}}} X_{\mathrm{pro}} \\
\rho_{11} & =k_{\mathrm{m}, \mathrm{ac}} \frac{S_{\mathrm{ac}}}{K_{\mathrm{S}, \mathrm{ac}}+S_{\mathrm{ac}}} X_{\mathrm{ac}} \\
\rho_{12} & =k_{\mathrm{m}, \mathrm{h} 2} \frac{S_{\mathrm{h} 2}}{K_{\mathrm{S}, \mathrm{h} 2}+S_{\mathrm{h} 2}} X_{\mathrm{h} 2} \\
\rho_{13} & =k_{\mathrm{dec} X_{\mathrm{su}}} X_{\mathrm{su}} \\
\rho_{16} & =k_{\mathrm{dec} X_{\mathrm{c} 4} X_{\mathrm{c} 4}} \\
\rho_{17} & =k_{\mathrm{dec} X_{\mathrm{pro}}} X_{\mathrm{pro}} \\
\rho_{18} & =k_{\mathrm{ac} X_{\mathrm{pro}}} X_{\mathrm{ac}} \\
\rho_{19} & =k_{\mathrm{h} 2 X_{\mathrm{pro}}} X_{\mathrm{h} 2} \\
\frac{d S}{d t} & =\Sigma_{j} \rho_{j} v_{i, j}
\end{aligned}
$$

\section{HASIL DAN DISKUSI}

Hasil simulasi pada Gambar 2a menunjukkan bahwa konsentrasi glukosa mengalami penurunan yang signifikan pada periode awal simulasi. Hal ini sangat berkaitan dengan besaran nilai parameter penguraian glukosa yang relatif lebih besar dibandingkan dengan parameter spesi yang lain. Selain itu, penguraian 
Ardhyka Dewantara et.al.

Implementasi Metode Runge-Kutta-Gill...

Tabel II: Nilai standar dari parameter ADM1 [4]

\begin{tabular}{|c|c||c|c||c|c|}
\hline Parameter & Nilai & Parameter & Nilai & Parameter & Nilai \\
\hline$k_{\mathrm{m}, \mathrm{su}}$ & 1.250 & $K_{\mathrm{S}, \mathrm{su}}$ & 500 & $Y_{\mathrm{su}}$ & 0.10 \\
$k_{\mathrm{m}, \mathrm{c} 4}$ & 0.833 & $K_{\mathrm{S}, \mathrm{c} 4}$ & 200 & $Y_{\mathrm{c} 4}$ & 0.06 \\
$k_{\mathrm{m}, \mathrm{pro}}$ & 0.542 & $K_{\mathrm{S}, \mathrm{pro}}$ & 100 & $Y_{\mathrm{pro}}$ & 0.04 \\
$k_{\mathrm{m}, \mathrm{ac}}$ & 0.333 & $K_{\mathrm{S}, \mathrm{ac}}$ & 150 & $Y_{\mathrm{ac}}$ & 0.05 \\
$k_{\mathrm{m}, \mathrm{h} 2}$ & 1.458 & $K_{\mathrm{S}, \mathrm{ac}}$ & $7 \times 10^{-3}$ & $Y_{\mathrm{h} 2}$ & 0.06 \\
$f_{\mathrm{Y}, \mathrm{su}}$ & 0.10 & $f_{\mathrm{bu}, \mathrm{su}}$ & 0.13 & $k_{\mathrm{dec}}$ & 0.000833 \\
$f_{\mathrm{Y}, \mathrm{c} 4}$ & 0.06 & $f_{\mathrm{pro}, \mathrm{su}}$ & 0.27 & & \\
$f_{\mathrm{Y}, \mathrm{pro}}$ & 0.04 & $f_{\mathrm{ac}, \mathrm{su}}$ & 0.41 & & \\
$f_{\mathrm{Y}, \mathrm{ac}}$ & 0.05 & $f_{\mathrm{h} 2, \mathrm{su}}$ & 0.19 & & \\
$f_{\mathrm{Y}, \mathrm{h} 2}$ & 0.06 & & & & \\
\hline
\end{tabular}

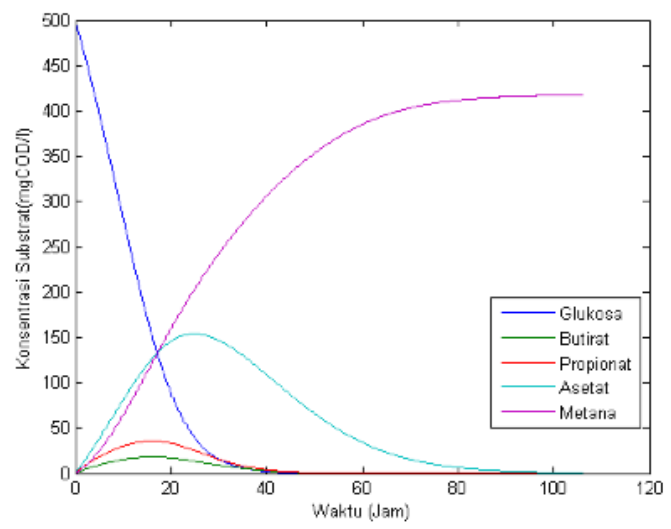

(a)

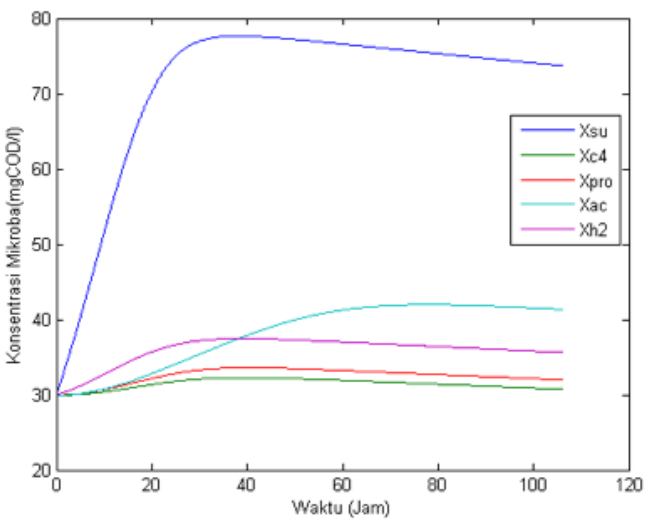

(b)

Gambar 2: Profil perubahan konsentrasi (a) substrat dan (b) mikroba selama simulasi.

glukosa sebagai substrat utama berbanding lurus dengan konsentrasi spesi asam yang dihasilkan, sehingga produksi tiga spesi asam, yaitu asam butirat, asam propionat dan asam asetat, di awal periode simulasi akan berkorelasi langsung dengan penguraian glukosa. Dari spesi asam sendiri, diketahui bahwa asam asetat dihasilkan secara signifikan dibandingkan dengan spesi asam yang lain karena posisinya sebagai spesi asam terakhir yang dihasilkan pada diagram proses biokimia (Gambar 1). Diagram tersebut juga menjelaskan faktor penyebab sedikitnya konsentrasi asam butirat yang dihasilkan karena posisinya sebagai asam pertama yang dihasilkan. Hal ini menyebabkan spesi asam tersebut akan berkurang secara signifikan karena terurai menjadi spesi asam yang lain. Selain itu, konsentrasi metana dihasilkan dengan konsentrasi terbanyak di akhir simulasi karena posisinya sebagai spesi terakhir pada diagram proses biokimia dan tidak adanya proses penguraian metana.

Profil perubahan konsentrasi mikroba pada Gambar 2b menunjukkan bahwa konsentrasi mikroba pengurai glukosa $\left(X_{\mathrm{su}}\right)$ mengalami kenaikan yang signifikan dibandingkan mikroba yang lain. Hal ini berbanding lurus dengan dengan laju penguraian glukosa pada periode awal simulasi. Dengan kata lain, aktivitas mikroba $X_{\mathrm{su}}$ berkorelasi langsung dengan penguraian glukosa sebagai substrat utama pada simulasi. Mikroba $X_{\mathrm{ac}}$ ditemukan sebagai mikroba kedua dengan laju penguraian yang tinggi. Hal ini berkaitan dengan produksi asam asetat sebagai spesi asam terbanyak yang dihasilkan. Besarnya laju produksi spesi asam ini diimbangi dengan aktivitas mikroba pengurainya.

Perbandingan konsentrasi metana hasil perhitungan dengan data eksperimen (Gambar 3a) menunjukkan bahwa akurasi perhitungan mulai menurun pada waktu simulasi 29 jam. Hal ini dikarenakan parameter standar yang digunakan tidak cocok untuk keseluruhan proses simulasi. Faktor lain yang menyebabkan inakurasi perhitungan adalah pengabaian beberapa kondisi, seperti inhibisi $\mathrm{pH}$ dan proses fisikokimia. Akurasi dapat diperbaiki dengan mengoptimasi parameter yang digunakan dengan metode optimasi [13], [14]. Uji T menghasilkan nilai $p 0.40$ pada tingkat kepercayaan $95 \%$ sehingga mengindikasikan bahwa variansi nilai metana hasil perhitungan dan data eksperimen berbeda. Bagaimanapun, uji $\mathrm{T}$ juga menghasilkan nilai signifikansi $>0.05$ sehingga menunjukkan bahwa kedua kelompok nilai tersebut sama 


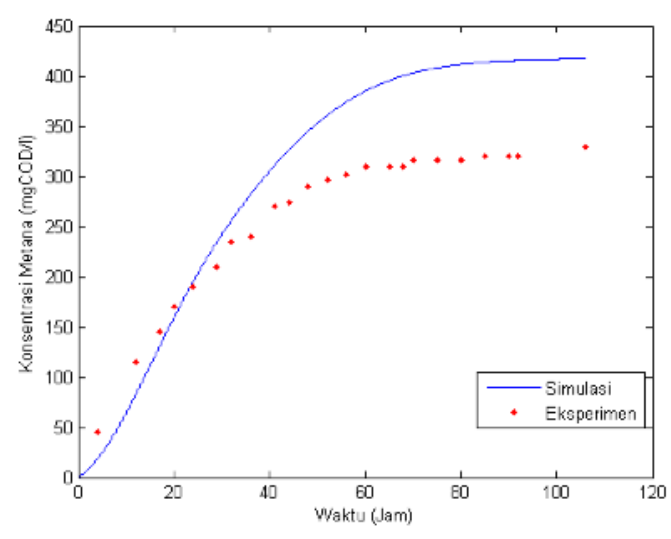

(a)

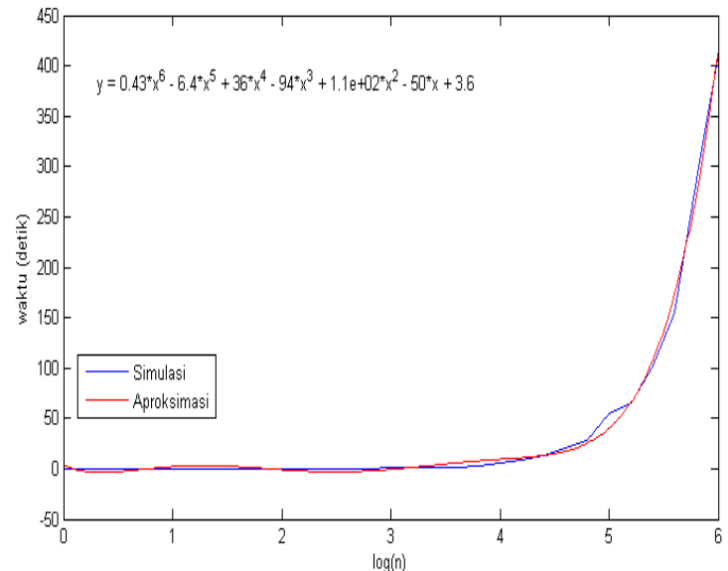

(b)

Gambar 3: (a) Perbandingan konsentrasi metana hasil perhitungan dengan data eksperimen [12], (b). Korelasi antara langkah simulasi dan total waktu simulasi yang diperlukan.

secara rata-rata. Analisis yang lain, MAPE, menunjukkan perhitungan dengan metode Runge-Kutta-Gill, dengan tingkat kesalahan perhitungan $22.949 \%$, lebih baik dibandingkan metode Runge-Kutta orde 4 , dengan tingkat kesalahan perhitungan $22.951 \%$.

Langkah simulasi pada metode numerik merupakan faktor krusial pada simulasi. Kesalahan dalam pemilihan langkah simulasi dapat menyebabkan gagalnya simulasi yang dilakukan karena akumulasi kesalahan yang terjadi. Pada dasarnya, pemilihan langkah simulasi yang sekecil mungkin dapat menghasilkan simulasi yang akurat. Akan tetapi, simulasi dengan langkah yang kecil akan mengakibatkan peningkatan waktu simulasi yang dibutuhkan. Oleh karena itu, korelasi antara langkah simulasi dengan total waktu simulasi diinvestigasi untuk dapat memprediksi waktu simulasi yang dibutuhkan dengan pemilihan langkah simulasi tertentu (Gambar 3b). Dengan mengaproksimasi kurva dengan persamaan polinomial, didapatkan persamaan untuk korelasi tersebut adalah $y=0.43 x^{6}-6.4 x^{5}+36 x^{4}-94 x^{3}+$ $1.1 e^{2} x^{2}-50 x+3.6$. Pada persamaan ini variabel $y$ dan $x$ secara berurutan merepresentasikan logaritma jumlah langkah dan waktu simulasi. Perlu diperhatikan bahwa persamaan tersebut hanya berlaku untuk simulasi produksi biogas dengan kondisi dan metode yang sama.

Pada kaitannya dengan korelasi konsentrasi awal glukosa dan metana, hasil simulasi (Gambar 4a) menunjukkan hubungan berbanding lurus antara kedua variabel tersebut. Pada setiap percobaan yang dilakukan, kenaikan jumlah konsentrasi metana yang dihasilkan konstan pada konsentrasi 83 mgCOD/l. Hasil simulasi yang lain (Gambar 4b) menunjukkan bahwa pengaruh konsentrasi awal mikroba tidak berpengaruh secara signifikan terhadap metana yang dihasilkan. Konsentrasi metana yang dihasilkan konstan pada saat konsentrasi awal mikroba lebih dari $30 \mathrm{mgCOD} / \mathrm{l}$. Hal ini menunjukkan bahwa konsentrasi awal mikroba bukan faktor penentu utama produksi metana.

\section{KESIMPULAN}

Hasil simulasi menunjukkan bahwa konsentrasi glukosa berkurang secara signifikan berbanding terbalik dengan produksi metana. Perhitungan akurasi dari simulasi tersebut mengindikasikan bahwa level akurasi perhitungan perlu ditingkatkan dengan menyesuaikan parameter dengan kondisi simulasi. Selain itu, produksi metana diketahui berkorelasi lebih kuat dengan konsentrasi awal glukosa dibandingkan konsentrasi mikroba. Analisis hasil simulasi menunjukkan bahwa konsentrasi metana dapat ditingkatkan dengan mempertimbangkan konsentrasi awal glukosa. Terkait dengan akurasi perhitungan, optimasi perlu dilakukan terhadap parameter ADM1 untuk meningkatkan akurasi. 
Ardhyka Dewantara et.al.

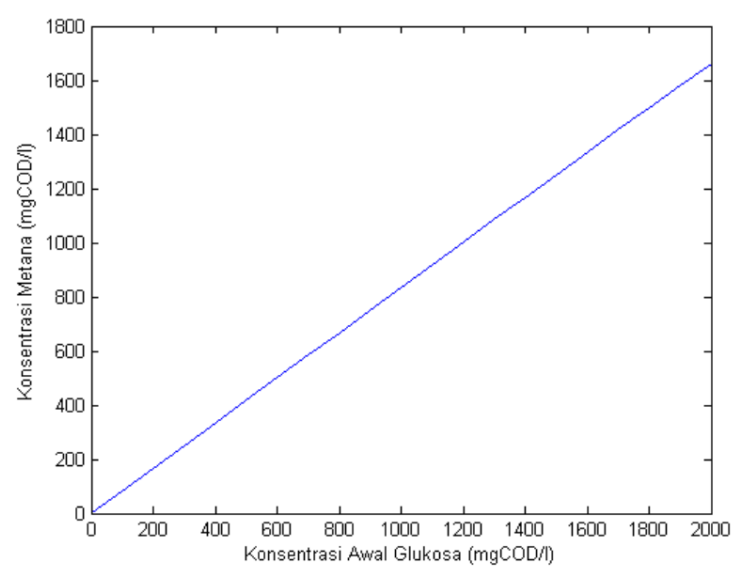

(a)

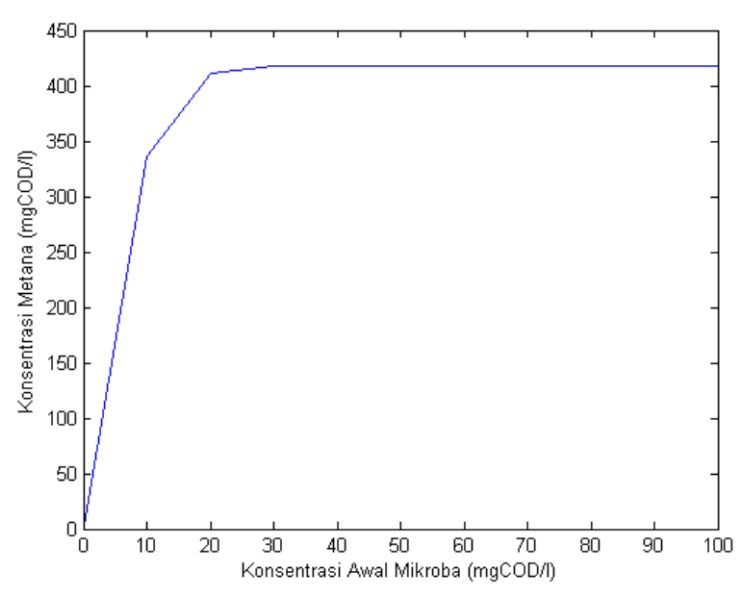

(b)

Gambar 4: Korelasi antara konsentrasi awal (a) glukosa (b) mikroba terhadap konsentrasi metana yang dihasilkan.

\section{REFERENSI}

[1] S. G. Gwavuya, S. Abele, I. Barfuss, M. Zeller, and J. MÃijller. (December, 2012). Household energy economics in rural Ethiopia: A cost-benefit analysis of biogas energy. Renewable Energy, 48:202-209.

[2] Joachim Clemens, Manfred Trimborn, Peter Weiland, and Barbara Amon. (February, 2006). Mitigation of greenhouse gas emissions by anaerobic digestion of cattle slurry. Agriculture, Ecosystems \& Environment, 112(2):171-177.

[3] Nathan Curry and Pragasen Pillay. (May, 2012). Biogas prediction and design of a food waste to energy system for the urban environment. Renewable Energy, 41:200-209.

[4] D. J. Batstone, J. Keller, I. Angelidaki, S. V. Kalyuzhnyi, S. G. Pavlostathis, A. Rozzi, W. T. M. Sanders, H. Siegrist, and V. A. Vavilin. (2002). The IWA Anaerobic Digestion Model No 1 (ADM1). Water Science and Technology: A Journal of the International Association on Water Pollution Research, 45(10):65-73.

[5] D. J. Batstone, J. Keller, and J. P. Steyer. (August, 2006). A review of ADM1 extensions, applications, and analysis: 2002âĂŞ2005. Water Science and Technology, 54(4):1-10.

[6] K. Derbal, M. Bencheikh-lehocine, F. Cecchi, A. H. Meniai, and P. Pavan. (February, 2009). Application of the IWA ADM1 model to simulate anaerobic co-digestion of organic waste with waste activated sludge in mesophilic condition. Bioresource Technology, 100(4):1539-1543.

[7] S. Soda, K. Wada, M. Okuda, and M. Ike. (March, 2011). Application of modified ADM1 to long-term experiments for methane/hydrogen production from model organic waste. Water Practice and Technology, 6(1):wpt2011009.

[8] S Satpathy, S Steinigeweg, F Uhlenhut, and E Siefert. (December, 2013). Application of Anaerobic Digestion Model 1 (ADM1) for Prediction of Biogas Production. International Journal of Scientific \& Engineering Research, 4(12):86-89.

[9] Liang Yu, Pierre Christian Wensel, Jingwei Ma, and Shulin Chen. (August, 2013). Mathematical Modeling in Anaerobic Digestion (AD). Journal of Bioremediation \& Biodegradation, 4:1-12.

[10] Robert J. Thompson. (December, 1970). Improving Round-off in Runge-Kutta Computations with Gill's Method. Commun. $A C M, 13(12): 739-740$.

[11] S. C. Oliveira. (February, 1999). Evaluation of effectiveness factor of immobilized enzymes using Runge-Kutta-Gill method: how to solve mathematical undetermination at particle center point? Bioprocess Engineering, 20(2):185-187.

[12] Hyeong-Seok Jeong, Chang-Won Suh, Jae-Lim Lim, Sang-Hyung Lee, and Hang-Sik Shin. (April, 2005). Analysis and application of ADM1 for anaerobic methane production. Bioprocess and Biosystems Engineering, 27(2):81-89.

[13] Jie Bai, He Liu, Bo Yin, and Huijun Ma. (November, 2015). Modeling of enhanced VFAs production from waste activated sludge by modified ADM1 with improved particle swarm optimization for parameters estimation. Biochemical Engineering Journal, 103:22-31.

[14] Isman Kurniawan and Annisa Aditsania. (March, 2016). Pemodelan Dan Simulasi Produksi Biogas Dari Substrat Glukosa Menggunakan Anaerobic Digestion Model No. 1 (ADM1). Indonesian Journal on Computing (Indo-JC), 1(1):49-60.

\section{Daftar Notasi}

\begin{tabular}{|c|c|c|}
\hline Notasi & Deskripsi & Satuan \\
\hline$\rho_{i}$ & Laju reaksi proses $i$ & kgCOD.kgCOD ${ }^{-1} \mathrm{~S}$ \\
\hline$v_{i, j}$ & Koefisien laju untuk komponen $i$ pada proses $j$ & \\
\hline$S_{i}$ & Komponen terlarut $i$ & $\mathrm{kgCOD} \cdot \mathrm{m}^{-3}$ \\
\hline$X_{i}$ & Komponen partikulat/mikroba $i$ & kgCOD. $\mathrm{m}^{-3}$ \\
\hline$k_{m}$ & Tetapan laju reaksi maksimum Monod spesifik & kgCOD.m ${ }^{-3} \_$S.kgCOD. $m^{-3} \_X . d^{-1}$ \\
\hline$K_{S}$ & Tetapan setengah jenuh Monod & $\mathrm{kgCOD} \cdot \mathrm{m}^{-3}$ \\
\hline$k_{d e c}$ & Tetapan laju peluruhan orde pertama mikroba & $d^{-1}$ \\
\hline
\end{tabular}

